\title{
Effects of Different Land Use Systems on Selected Physico-Chemical Properties of Soils in Northwestern Ethiopia
}

\author{
Yihenew G. Selassie ${ }^{1} \&$ Getachew Ayanna ${ }^{2}$ \\ ${ }^{1}$ Department of Natural Resources Management, College of Agriculture and Environmental Sciences, Bahir Dar \\ University, Bahir Dar, Ethiopia \\ ${ }^{2}$ Graduate Program, Haromaya University, Haromaya, Ethiopia \\ Correspondence: Yihenew G. Selassie, Department of Natural Resources Management, College of Agriculture \\ and Environmental Sciences, Bahir Dar University, Bahir Dar, Ethiopia. Tel: 251-918-765-823. \\ E-mail: yihenewgs@gmail.com
}

Received: December 21, 2012 Accepted: February 16, 2013 Online Published: March 15, 2013

doi:10.5539/jas.v5n4p112 URL: http://dx.doi.org/10.5539/jas.v5n4p112

\begin{abstract}
Information about effects of different land use systems on soil physico-chemical properties is crucial for best land management practices. This study was, therefore, conducted to evaluate the same on Nitosols of Achefer District, Northwestern Ethiopia. The landuse systems studied included grassland, cultivated land, plantation forest and natural forest. The research was superimposed on land use systems that were located nearby on similar soil, contour line and slope classes. Undisturbed core and disturbed composite soil samples were collected randomly from two sites with three replications for each landuse system at two varying depths $(0-15 \mathrm{~cm}$ and $15-30 \mathrm{~cm})$. The undisturbed soil samples were analysed for bulk density, particle density, porosity and moisture content at different pressures; while the composite soil samples were analyzed for $\mathrm{pH}$, organic carbon, total $\mathrm{N}$ and available $\mathrm{P}$. Results of the study indicated that the lowest bulk and particle densities, the highest total porosity, and higher moisture content at both field capacity and permanent wilting percentage were found under natural forest land use system. In contrast, the highest bulk and particle densities, the lowest total porosity and lower water contents at both field capacity and permanent wilting percentage were obtained under the cultivated landuse system. Soil $\mathrm{pH}$ was moderately acidic under all landuse systems. The lowest organic carbon, total N, and C:N ratio were recorded under cultivated land; whereas the highest values of the same parameters were found under natural forest. In all landuse systems, organic carbon and total $\mathrm{N}$ decreased with soil depth. The highest and lowest available $\mathrm{P}$ contents were recorded under natural forest and grassland, respectively. From the results of the study it was possible to conclude that conversion of forest lands to cultivated and grasslands had detrimental effects on the soil physico-chemical properties under subsistance farming systems of the study area. It is, therefore, recommended that appropriate and integrated land management options for different land use syetems are required to sustain agricultural productivity while protecting the environment.
\end{abstract}

Keywords: land use systems, bulk density, available water organic matter, total N, soil pH, available phosphorus

\section{Introduction}

Rapid increase in population demands more production of food, fodder, fiber and fuel from the land. Highlands of Ethiopia, with altitude above 1500 meters above sea level (m.a.s.l), are the dominant sources of water, crop production and fodder. They are densely populated and hold about $90 \%$ human and about two-thirds of livestock population. The highlands cover about $50 \%$ of the land area with $95 \%$ of the cropping land accounting for over $90 \%$ of the country's economy (Gete, 2002). To meet these needs, vast tracts of land are being put under intensive cropping and large areas of grasslands are being overgrazed and degraded in Ethiopia. Additionally, new and often marginal lands are being brought into production. Soil resources are finite, non-renewable and prone to degradation through misuse and mismanagement (Lal, 2000). In addition, intensive agriculture, combined with dynamic population and long-term exploitative farm practices, have led to the continuous depletion of the natural vegetation cover and over-utilization of land resources. Moreover, due to an increasing demand for firewood, timber, pasture, food, and residential dwelling, the hardwood forests are being degraded or converted to cropland at an alarming rate in the study area. Under such situations, soil degradation is inevitable (Ronggui, 2001). 
Forest cover in the Ethiopian highlands as a whole decreased from $46 \%$ to $2.7 \%$ of the land area between the 1950s and the late 1980s (USAID, 2004). Though the forest resource is very limited, its demand remains high. According to the Ethiopian Forestry Action Programme (EFAP, 1994), the national demand for woody biomass was estimated at 50 million $\mathrm{m}^{3}$, of which $90 \%$ is in the form of fuel wood. The supply was estimated to be only 14.4 million $\mathrm{m}^{3}$, indicating a deficit of some 35.6 million $\mathrm{m}^{3}$ or $71 \%$ of the demand (ADF, 2001).

Environmental degradation caused by inappropriate land use is a worldwide problem that has attracted attention in sustainable agricultural production systems (Vagen et al., 2006; Khormali \& Nabiollahy, 2009). Soil nutrients are closely related to agricultural land use types and their associated management practices (Agbede, 2010; Wang et al., 2010). There is considerable concern that land use change could alter cycles of soil carbon (C) (Houghton, 1999) and nitrogen (N) (Potter et al., 1996). Agricultural cultivation is known to decrease carbon storage (Davidson \& Ackerman, 1993; Solomon et al., 2002), and result in a net flux of carbon to the atmosphere (Schlesinger, 1984). Moreover, successful crop production requires the sustainable use of the soil resource, because of the decline in soil quantity within a short period of time. Hence, it is apparent that restoration of marginal lands has high priority. However, it is possible only through a good understanding of the physical, chemical and biological properties and the resilience characteristics of the soils (Brady \& Weil, 2002). The study area is facing the problems of deforestation, overgrazing, poor soil management and severe erosion. For combating and minimizing the on-going soil degradation and enhance land productivity through sustainable use of soil resources, it requires understanding the soil physico-chemical characteristics of different land use systems. However, very little information is available about the study area. Therefore, the present study was undertaken to evaluate the effect of different land use systems on selected physical and chemical properties of different land use systems on Nitosols of Achefer District, Northwestern Ethiopia.

\section{Materials and Methods}

\subsection{Description of the Study Area}

The study was conducted at Abechikeli Mariam and Aferfida Georgis rural villages in Achefer District, West Gojjam Zone of the Amhara National Regional State (ANRS), Northwestern Ethiopia (Figure 1). The center of the District is situated at $11^{\circ} 21^{\prime} \mathrm{N}$ latitude and $36^{\circ} 56^{\prime} \mathrm{E}$ longitude, $486 \mathrm{~km}$ north-west of Addis Ababa and $60 \mathrm{~km}$ south of Bahir Dar, the capital of ANRS. The District has altitude ranging from 1500-2500 m.a.s.l.; mean total annual rainfall of $1530 \mathrm{~mm}$; and mean monthly minimum and maximum temperatures are 8.4 and $28.0^{\circ} \mathrm{C}$, respectively. Soils of the study area are grouped as Nitosols (Mesfin, 1998).

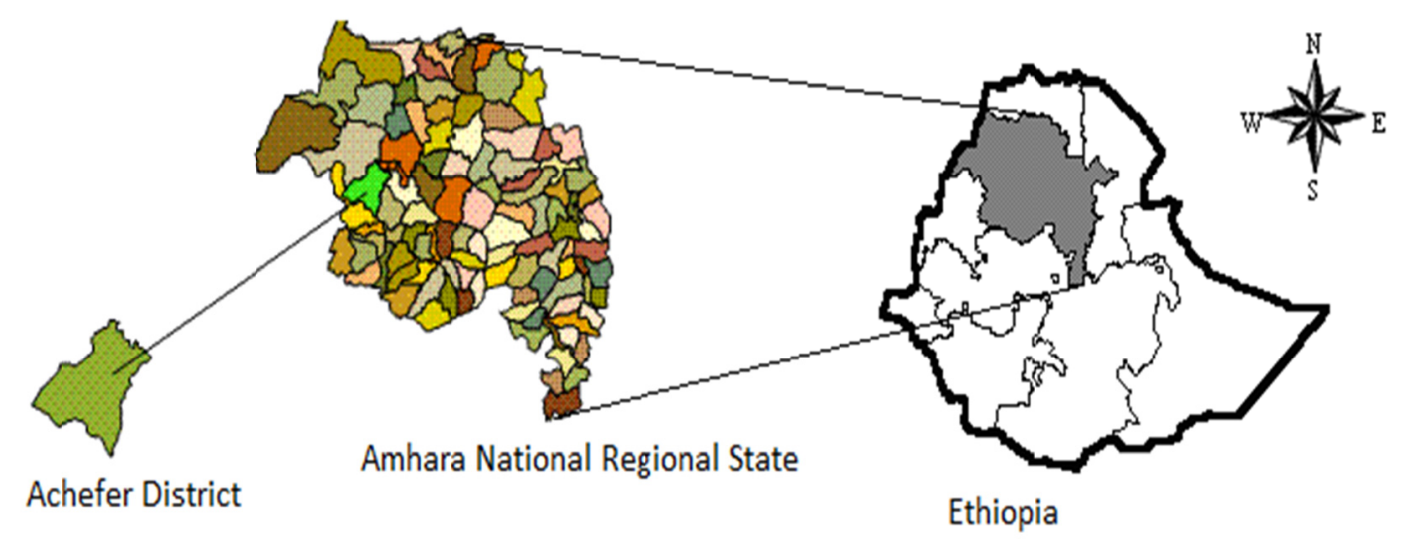

Figure 1. Location of the study area

\subsection{Research Methodology}

The research was superimposed on land use systems that were located on adjacent fields of similar soil types, contour line and slope classes. The different land use systems covered in the research were the following.

1) Cultivated land under rain fed maize production for nine years under lower inputs;

2) Grassland with communal grazing areas having no cultivation for more than 26 years;

3) Natural forest (church forest) for more than 50 years; 
4) Plantation forest under Eucalyptus camaldulensis since 1998.

The four land use systems were selected at two sites (Abechikli Mariam and Aferfida Georgis). Composite soil samples of the two sites were collected randomly from the four land use systems at two depths (0-15 and 15-30 cm). Undisturbed core samples were also collected from the surface layers of the four land use systems using a core sampler to determine the bulk density (BD), particle density (PD), total porosity, field capacity (FC), permanent wilting percentage (PWP), and total available water content (AWC). The BD was determined as the ratio of oven-dry soil mass to its volume (Blake \& Hartge, 1986) and PD was estimated by pycnometer method (Barauah \& Barthakulha, 1997). The values of BD and PD were used to compute the total porosity. Soil moisture contents (SMC) were determined at water potentials of $-33 \mathrm{kPa}$ bar for FC; and $-1500 \mathrm{kPa}$ for PWP using pressure membrane apparatus. Available water was computed by subtracting the SMC content (\%) at PWP from SMC content (\%) at FC (Klute, 1965) and expressed as depth of water for respective soil sampling depth.

Additionally, triplicate disturbed composite samples for each study unit were collected for a total of forty eight samples were collected for the study. These samples were used to analyze soil chemical properties. Soil pH was measured potentiometrically in a 1:2.5 soil-water solution, using a combined glass electrode $\mathrm{pH}$ meter (Thomas, 1996). Total $\mathrm{N}$ content in the soil samples was determined by Kjeldahl method (Jackson, 1958), soil organic carbon (OC) by wet oxidation method (Walkley \& Black, 1934) and available P by Olsen method (Sahlemedhin \& Taye, 2000).

\subsection{Statistical Analysis}

Analysis of variance (ANOVA) test was done to see the presence of significant difference among the treatments. In conditions where there was significant difference, mean comparison was performed with Duncan's multiple range test (DMRT) using SAS software (SAS, 1997).

\section{Results and Discussion}

\subsection{Soil Physical Properties}

The results of soil analyses on bulk density (BD), particle density (PD) and total porosity (TP) of different land use systems at the two sites are presented in Table 1 . The highest BD $(0-15 \mathrm{~cm})$ was found in the cultivated land at both Abechikeli Mariam $\left(1.41 \mathrm{Mg} \mathrm{m}^{-3}\right)$ and Aferfida Georgis $\left(1.40 \mathrm{Mg} \mathrm{m}^{-3}\right)$ followed by the soil under Eucalyptus plantations. In contrast, the lowest BD values of 1.18 and $1.08 \mathrm{Mg} \mathrm{m}^{-3}$ were observed under the natural forest at the respective sites. The high bulk density under cultivated lands was due to the trampling effects. The results were in agreement with that of Islam and Weil (2000). The grassland had lower bulk density than the cultivated land which could be due to restricted grazing at the grassland to harvest fodder and free grazing on crop lands after harvest and continuous ploughing at the same depth of cultivated lands. Evrendilek et al. (2004) also reported that conversion of grassland into cultivated land during a 12 -year period increased BD by $10.5 \%$ but decreased TP by $9.1 \%$. Moreover, in uncultivated land, there was relatively higher organic matter $(\mathrm{OM})$ making the soil loose, porous and well-aggregated that might have reduced the BD. The BD was negatively correlated with OM $(r=-0.97 * * *)$ and increased with soil depth for all land use systems. Similar results were reported by Celik (2005).

At both sites, the particle densities of the different land use systems were significantly different, except between grassland and Eucalyptus plantation (Table 1). The highest PD of 2.6 and $2.63 \mathrm{Mg} \mathrm{m}^{-3}$ were recorded at $15-30 \mathrm{~cm}$ (cultivated lands), whereas the lowest were at $0-15 \mathrm{~cm}$ (natural forest) of the Abechikeli Mariam $\left(2.41 \mathrm{Mg} \mathrm{m}^{-3}\right)$ and Aferfida Georgis sites $\left(2.40 \mathrm{Mg} \mathrm{m}^{-3}\right)$. In unprotected cultivated lands, the finer soil particles will be selectively removed by erosion, thereby increasing the proportion of the coarser particles in the soil which leaves more sand particles (Ayoubi et al., 2011) that increases particle density. In similar soil types, keeping other things constant, soils with higher proportion of sand particles have higher particle density than otherwise (Brady \& Weil, 2002). Particle density increased with depth, which could be due to the reduction of soil OM with increasing depth. High values of total porosities (63.47 and 66.98\%) were found at $0-15 \mathrm{~cm}$ depth under the natural forest, whereas the lowest values (45.63 and 45.58\%) were obtained at the $15-30 \mathrm{~cm}$ depth under cultivated land of Abechikeli Mariam and Aferfida Georgis sites, respectively. Porosity decreased with soil depth which could be attributed to accumulation of organic matter in surface soil under natural forest. 
Table 1. Soil bulk density, particle density and total porosity under the different land use systems and soil depths at Abechikeli Mariam and Aferfida Georgis sites of Achefer District, Northwestern Ethiopia

\begin{tabular}{|c|c|c|c|c|c|c|c|c|c|c|c|c|}
\hline \multirow{4}{*}{$\begin{array}{l}\text { Land } \\
\text { type }\end{array}$} & \multicolumn{6}{|c|}{ Abechikeli Mariam* } & \multicolumn{6}{|c|}{ Aferfida Georgis $^{*}$} \\
\hline & \multirow[t]{2}{*}{$\mathrm{BD}$} & \multicolumn{3}{|c|}{ PD } & \multirow{2}{*}{\multicolumn{2}{|c|}{$\begin{array}{l}\mathrm{TP} \\
(\%)\end{array}$}} & \multicolumn{2}{|c|}{$\mathrm{BD}$} & \multicolumn{2}{|c|}{ PD } & \multirow{2}{*}{\multicolumn{2}{|c|}{$\begin{array}{l}\mathrm{TP} \\
(\%)\end{array}$}} \\
\hline & & \multicolumn{3}{|c|}{$\left(\mathrm{Mg} \mathrm{m}^{-3}\right)$} & & & \multicolumn{4}{|c|}{$\left(\mathrm{Mg} \mathrm{m}^{-3}\right)$} & & \\
\hline & $\begin{array}{l}0-15 \\
\mathrm{~cm}\end{array}$ & $\begin{array}{c}15-30 \\
\mathrm{~cm}\end{array}$ & $\begin{array}{c}0-15 \\
\mathrm{~cm}\end{array}$ & $\begin{array}{c}15-30 \\
\mathrm{~cm}\end{array}$ & $\begin{array}{c}0-15 \\
\mathrm{~cm}\end{array}$ & $\begin{array}{c}15-30 \\
\mathrm{~cm}\end{array}$ & $\begin{array}{c}0-15 \\
\mathrm{~cm}\end{array}$ & $\begin{array}{c}15-30 \\
\mathrm{~cm}\end{array}$ & $\begin{array}{c}0-15 \\
\mathrm{~cm}\end{array}$ & $\begin{array}{c}15-30 \\
\mathrm{~cm}\end{array}$ & $\begin{array}{c}0-15 \\
\mathrm{~cm}\end{array}$ & $\begin{array}{c}15-30 \\
\mathrm{~cm}\end{array}$ \\
\hline Grass land & $1.23^{\mathrm{c}}$ & $1.31^{\mathrm{b}}$ & $2.46^{\mathrm{b}}$ & $2.54^{\mathrm{b}}$ & $49.65^{b}$ & $48.42^{\mathrm{b}}$ & $1.23^{\mathrm{c}}$ & $1.32^{\mathrm{b}}$ & $2.46^{\mathrm{b}}$ & $2.56^{\mathrm{b}}$ & $49.99^{b}$ & $48.49^{b}$ \\
\hline $\begin{array}{l}\text { Cultivated } \\
\text { land }\end{array}$ & $1.41^{\mathrm{a}}$ & $1.45^{\mathrm{a}}$ & $2.59^{\mathrm{a}}$ & $2.65^{\mathrm{a}}$ & $45.63^{\mathrm{c}}$ & $45.09^{\mathrm{d}}$ & $1.40^{\mathrm{a}}$ & $1.46^{\mathrm{a}}$ & $2.57^{\mathrm{a}}$ & $2.63^{\mathrm{a}}$ & $45.58^{\mathrm{c}}$ & $44.55^{\circ}$ \\
\hline $\begin{array}{l}\text { Eucalyptus } \\
\text { plantation }\end{array}$ & $1.29^{\mathrm{b}}$ & $1.34^{\mathrm{b}}$ & $2.48^{\mathrm{b}}$ & $2.51^{\mathrm{b}}$ & $48.05^{\mathrm{c}}$ & $46.75^{\mathrm{c}}$ & $1.30^{\mathrm{b}}$ & $1.35^{\mathrm{b}}$ & $2.48^{\mathrm{b}}$ & $2.51^{\mathrm{c}}$ & $47.44^{\mathrm{c}}$ & $46.35^{\mathrm{c}}$ \\
\hline $\begin{array}{l}\text { Natural } \\
\text { forest }\end{array}$ & $1.18^{\mathrm{d}}$ & $1.13^{\mathrm{c}}$ & $2.41^{\mathrm{c}}$ & $2.46^{\mathrm{c}}$ & $63.47^{\mathrm{a}}$ & $54.06^{\mathrm{a}}$ & $1.08^{\mathrm{d}}$ & $1.18^{\mathrm{c}}$ & $2.40^{\mathrm{c}}$ & $2.46^{\mathrm{d}}$ & $66.98^{\mathrm{a}}$ & $51.95^{\mathrm{a}}$ \\
\hline
\end{tabular}

${ }^{*}$ Means within a column followed by the same letter are not significantly different at $\mathrm{p} \leq 0.05$;

$\mathrm{BD}=$ bulk density; $\mathrm{PD}=$ particle density; $\mathrm{TP}=$ total porosity

At field capacity (FC), natural forest retained the highest moisture content of 35.67 and $35.98 \%$ at 15 to $30 \mathrm{~cm}$ while the lowest moisture content of 30.78 and $33.12 \%$ at the same depth were observed under the natural forest and cultivated land of Abechikeli Mariam and Aferfida Georgis sites, respectively (Table 2). Cultivation deteriorates soil structural aggregation reducing the soil water retention capacity (Wekene, 2001). The moisture content at FC of Abechikeli Mariam site negatively correlated with BD and PD ( $\mathrm{r}=-0.86^{* *}$ and $-0.96 * * *$ at $0-15$ $\mathrm{cm}$ depth; and $\mathrm{r}=-0.88^{* *}$ and $-0.78^{* *}$ at $15-30 \mathrm{~cm}$ depth, respectively). On the other hand, it was positively correlated with $\mathrm{OM}$ and total $\mathrm{N}(\mathrm{r}=0.91 * * *$ and $0.92 * * *$ at $0-15 \mathrm{~cm}$ depth; and $0.82 * *$ and $0.79 * *$ at $15-30 \mathrm{~cm}$ depths, respectively). Soil moisture content at FC for all land use systems showed an increasing trend with depth. The highest water content at permanent wilting point (PWP) of $22.30 \%$ and $23.28 \%$ were found under the natural forest of Abechikeli Mariam and grass land of Aferfida Georgis, respectively; whereas the lowest values $(20.42 \%$ and 21.14\%) were found under the cultivated land at Abechikeli Mariam and forest land of Aferfida Georgis sites, respectively.

Total available water was the highest in natural forestland followed by grassland in both soil sampling depths and sites. Higher clay and OC provided large surface area required for absorption and retention of water molecules (Materechera \& Mkhabela, 2001). Natural forest soils have more available water holding capacity compared to the cultivated lands (Ayoubi, 2011). It is apparent, however, that soils with clayey texture have high moisture retention at field capacity and at permanent wilting point making the available water to crops to be lower than loam textured soils (Brady \& Weil, 2002).

Table 2. Soil moisture content of different land use systems and depths at Abechikeli Mariam and Aferfida Georgis sites of Achefer District

\begin{tabular}{|c|c|c|c|c|c|c|c|c|c|c|c|c|}
\hline \multirow[t]{4}{*}{ Land use } & \multicolumn{6}{|c|}{ Abechikeli Mariam } & \multicolumn{6}{|c|}{ Aferfida Georgis } \\
\hline & \multicolumn{12}{|c|}{ Moisture content* } \\
\hline & \multicolumn{2}{|c|}{$\mathrm{FC}(\%)$} & \multicolumn{2}{|c|}{ PWP (\%) } & \multicolumn{2}{|c|}{$\mathrm{AWC}(\mathrm{mm})$} & \multicolumn{2}{|c|}{$\mathrm{FC}(\%)$} & \multicolumn{2}{|c|}{ PWP (\%) } & \multicolumn{2}{|c|}{$\mathrm{AWC}(\mathrm{mm})$} \\
\hline & $\begin{array}{l}0-15 \\
\mathrm{~cm}\end{array}$ & $\begin{array}{c}15-30 \\
\mathrm{~cm}\end{array}$ & $\begin{array}{c}0-15 \\
\mathrm{~cm}\end{array}$ & $\begin{array}{c}15-30 \\
\mathrm{~cm}\end{array}$ & $\begin{array}{l}0-15 \\
\mathrm{~cm}\end{array}$ & $\begin{array}{c}15-30 \\
\mathrm{~cm}\end{array}$ & $\begin{array}{l}0-15 \\
\mathrm{~cm}\end{array}$ & $\begin{array}{c}15-30 \\
\mathrm{~cm}\end{array}$ & $\begin{array}{c}0-15 \\
\mathrm{~cm}\end{array}$ & $\begin{array}{c}15-30 \\
\mathrm{~cm}\end{array}$ & $\begin{array}{l}0-15 \\
\mathrm{~cm}\end{array}$ & $\begin{array}{c}15-30 \\
\mathrm{~cm}\end{array}$ \\
\hline Grass land & $34.38^{\mathrm{b}}$ & $36.22^{\mathrm{a}}$ & $21.98^{\mathrm{a}}$ & $23.23^{\mathrm{a}}$ & $22.88 b$ & $25.53 \mathrm{a}$ & $34.43^{\mathrm{a}}$ & $35.69^{\mathrm{a}}$ & $22.56^{\mathrm{a}}$ & $23.28^{\mathrm{a}}$ & $21.90 \mathrm{~b}$ & $24.57 b$ \\
\hline $\begin{array}{l}\text { Cultivated } \\
\text { land }\end{array}$ & $30.78^{d}$ & $32.80^{\mathrm{c}}$ & $20.42^{\mathrm{b}}$ & $21.55^{\mathrm{b}}$ & $21.91 \mathrm{a}$ & $24.47 \mathrm{~b}$ & $33.12^{\mathrm{b}}$ & $33.71^{\mathrm{b}}$ & $22.64^{\mathrm{a}}$ & $22.47^{\mathrm{b}}$ & $22.01 b$ & $24.62 b$ \\
\hline $\begin{array}{l}\text { Eucalyptus } \\
\text { plantation }\end{array}$ & $33.22^{\mathrm{c}}$ & $34.17^{\mathrm{b}}$ & $21.28^{\mathrm{a}}$ & $22.45^{\mathrm{ab}}$ & $23.10 \mathrm{c}$ & $23.56 \mathrm{c}$ & $33.93^{\mathrm{ab}}$ & $34.87^{\mathrm{a}}$ & $22.62^{\mathrm{a}}$ & $22.30^{\mathrm{b}}$ & $22.05 b$ & $25.45 a$ \\
\hline Natural forest & $35.67^{\mathrm{a}}$ & $37.07^{\mathrm{a}}$ & $22.30^{\mathrm{a}}$ & $23.03^{\mathrm{a}}$ & $23.66 \mathrm{a}$ & $25.90 \mathrm{a}$ & $33.86^{\mathrm{ab}}$ & $35.98^{\mathrm{a}}$ & $21.14^{\mathrm{b}}$ & $22.47^{b}$ & $23.09 a$ & $25.33 a$ \\
\hline
\end{tabular}

* Means within a column followed by the same letter are not significantly different at $p \leq 0.05$;

$\mathrm{FC}=$ field capacity; PWP $=$ permanent wilting point; $\mathrm{AWC}=$ available water. 


\subsection{Soil Chemical Properties}

The highest soil $\mathrm{pH}$ values of 5.61 and 5.52 in surface soil were found under the grassland; whereas, the lowest $\mathrm{pH}$ values of 5.06 and 5.01 were registered under the Eucalyptus plantation at Abechikeli Mariam and Aferfida Georgis sites, respectively (Table 3). The soil $\mathrm{pH}$ range of 5.01-5.61 indicated moderately acidic soil condition under all the land use systems. Soils under Eucalyptus plantations were more acidic, owing to more uptakes of basic cations by the trees and poor return rate to the soil. The relative decline in soil $\mathrm{pH}$ at the soil surface of the soils under Eucalyptus plantation and natural forest land could be also due to oblong shaped canopy leading the rain to form big drops consequently enhancing leaching of basic cations as well by releasing organic acids associated with mineralization of organic matter (Mohammed et al., 2005). Soil pH increased consistently with depth in all land use systems. This pattern of variability in soil $\mathrm{pH}$ suggested the increase in bases with increase in depth that could be attributed to the downward movement of solutes by leaching within a profile (Mohammed et al., 2005). Malo et al. (2005) also reported that the increase in $\mathrm{pH}$ with soil depth could be associated with enhanced carbonate levels and less weathering rates.

The organic carbon (OC) content varied widely under different land use systems. At 0 to $15 \mathrm{~cm}$ soil depth, it ranged between 0.92 in cultivated land at Aferfida Georgis to $4.94 \%$ in the natural forestland at Abechikeli Mariam (Table 3). Based on the ratings of Landon (1991), it was very low in cultivated land and medium under natural forest land. The OC contents at both depths were higher at the natural forestland than the cultivated land at both sites. It could be attributed to improved aeration that promoted mineralization of $\mathrm{OC}$ or owing to the little or no return of plant residues and manures into the soils. The conversion of forest ecosystem to other forms of land cover may decrease the stock of $\mathrm{OC}$ due to changes in soil moisture and temperature regimes, and succession of plant species with differences in quantity and quality of biomass returned to the soil (Offiong \& Iwara, 2012). Evrendilek et al. (2004) showed that deforestation and subsequent cultivation decreased organic matter by $48.8 \%$. Moreover, the conversion of forest into cropland is known to deteriorate soil physical properties and making the land more susceptible to erosion since macro-aggregates are disturbed (Çelik, 2005). OC is a powerful indicator for assessing soil potential productivity (Shukla et al., 2006). The relatively higher OC in soils at upper depth in all land use systems could be due to relatively better return of biomass for decomposition at the surface. Wakene (2001) also reported surface soil horizons to be more biologically active in the soil systems.

Total $\mathrm{N}$ contents of the soil were highly affected by the different land use systems. Total soil $\mathrm{N}$ at 0 to $15 \mathrm{~cm}$ depth varied from $0.07 \%$ under cultivated land at Aferfida Georgis to $0.26 \%$ under natural forest land at Abechikeli Mariam and declined with depth. The presence of dense vegetation affords the soil adequate cover thereby reducing the loss in macro and micro nutrients that are essential for plant growth and energy fluxes (Iwara et al., 2011). Its status was low in the cultivated land, eucalyptus plantation at both depths and sites and grassland at 15 to $30 \mathrm{~cm}$ in both sites. Medium total $\mathrm{N}$ was registered under natural forestland at Aferfida Georgis at both soil depths and at the upper depth of Abechikeli Mariam. Moreover, the $\mathrm{N}$ content of natural forestland at 0 to $15 \mathrm{~cm}$ at Abechikeli Mariam could be rated as high (Havlin et al., 1999). Ayoubi et al. (2011) reported that natural forest soils had more TN as compared to the cultivated lands. Heluf and Wakene (2006) recorded the highest total N on surface soil layers of virgin lands compared to research and farmers' fields. Total nitrogen decreased consistently with depth under all land use systems corresponding to the findings of Gong et al. (2005), Geissen and Guzman (2006) and Alemayhu (2007). Total nitrogen had positive and significant correlation with organic carbon content of the soil $\left(\mathrm{r}=0.99^{* *}\right)$ at both soil depths and sites. Fisseha (1992) reported highly significant correlation $(\mathrm{p}<0.01)$ between nitrogen and organic matter contents of Vertisolss at Shoa Robit $(r=0.90)$, Debre Zeit $(r=0.96)$ and Sheno $(r=0.99)$ sites of Ethiopia.

The available phosphorus (AP) content of all land use systems ranged from 2.61-4.91 (0-15 cm soil depth) and $1.88-3.70 \mathrm{mg} \mathrm{kg}^{-1}$ (15-30 cm soil depth) revealing that all soils were deficient in AP according to Thomas (2000). Among the land use systems, the natural forestland contained relatively higher concentration of AP as a result of high organic matter which released phosphorus during its mineralization. AP in all land use systems decreased with increasing soil depth. This could be due to the increased clay and reduced OM content with increasing depth of the soil. Organic compounds in soils increase $\mathrm{P}$ availability by the formation of organophosphate complexes that are more easily assimilated by plants, anion replacement of $\mathrm{H}_{2} \mathrm{PO}_{4}$ from adsorption sites, the coating of $\mathrm{Fe} / \mathrm{Al}$ oxides by humus to form a protective cover and reduced phosphorus fixation. Moreover, decomposing of OM releases acids that increase the solubility of calcium phosphates (Ahn, 1993; Thompson \& Troeh, 1993; Havlin et al., 1999). Available $\mathrm{P}$ was positively correlated with $\mathrm{OC}$ at 0 to $15 \mathrm{~cm}$ soil depth $\left(\mathrm{r}=0.68^{* *} ; \mathrm{r}=0.72 * *\right)$ and 15 to $30 \mathrm{~cm}$ soil depth $\left(r=0.61^{* *} ; r=0.63^{* *}\right)$ for Abechikeli Mariam and Aferfida Georgis sites, respectively. The results were in agreement with the reports of Yihenew (2002) who indicated that OC positively correlated with AP. 
Moreover, Berhane and Sahlemedhin (2003), Zewdu et al. (2004) and Tuma (2007) reported that available phosphorus contents of the surface soils were higher than that of sub soils.

Table 3. Selected soil chemical properties of different land use systems of Abechikeli Mariam and Aferfida Georgis sites of Achefer District

\begin{tabular}{|c|c|c|c|c|c|c|c|c|c|c|}
\hline \multirow{3}{*}{ Land Use } & \multicolumn{5}{|c|}{ Abechikeli Mariam* } & \multicolumn{5}{|c|}{ Aferfida Georgis ${ }^{*}$} \\
\hline & \multirow{2}{*}{$\begin{array}{c}\mathrm{pH} \\
(1: 2.5 \\
\left.\text { soil- } \mathrm{H}_{2} \mathrm{O}\right)\end{array}$} & $\mathrm{OC}$ & $\mathrm{TN}$ & \multirow[b]{2}{*}{$\mathrm{C}: \mathrm{N}$} & \multirow{2}{*}{$\begin{array}{c}\mathrm{AP} \\
(\mathrm{mg} \\
\left.\mathrm{kg}^{-1}\right)\end{array}$} & \multirow{2}{*}{$\begin{array}{c}\mathrm{pH} \\
(1: 2.5 \\
\left.\text { soil- } \mathrm{H}_{2} \mathrm{O}\right)\end{array}$} & \multicolumn{2}{|c|}{ OC $\quad \mathrm{TN}$} & \multirow[b]{2}{*}{$\mathrm{C}: \mathrm{N}$} & \multirow{2}{*}{$\begin{array}{c}\mathrm{AP} \\
(\mathrm{mg} \\
\left.\mathrm{kg}^{-1}\right)\end{array}$} \\
\hline & & \multicolumn{2}{|c|}{$(\%)$} & & & & $(9$ & & & \\
\hline & \multicolumn{10}{|c|}{0 to $15 \mathrm{~cm}$ depth } \\
\hline Grass Land & $5.61^{\mathrm{a}}$ & $2.84^{\mathrm{b}}$ & $0.17^{\mathrm{b}}$ & $16.7^{\mathrm{b}}$ & $2.67^{\mathrm{d}}$ & $5.52^{\mathrm{a}}$ & $2.80^{\mathrm{b}}$ & $0.15^{\mathrm{b}}$ & $18.7^{\mathrm{b}}$ & $2.61^{\circ}$ \\
\hline $\begin{array}{l}\text { Cultivated } \\
\text { Land }\end{array}$ & $5.37^{\mathrm{b}}$ & $0.99^{\mathrm{d}}$ & $0.08^{\mathrm{d}}$ & $11.9^{\mathrm{d}}$ & $3.15^{\mathrm{c}}$ & $5.21^{\mathrm{b}}$ & $0.92^{\mathrm{d}}$ & $0.07^{\mathrm{d}}$ & $13.1^{\mathrm{d}}$ & $3.26^{\mathrm{c}}$ \\
\hline Eucalyptus & $5.06^{\mathrm{c}}$ & $1.95^{\mathrm{c}}$ & $0.13^{\mathrm{c}}$ & $14.7^{\mathrm{c}}$ & $3.84^{\mathrm{b}}$ & $5.01^{\mathrm{c}}$ & $1.93^{\mathrm{c}}$ & $0.11^{\mathrm{c}}$ & $17.5^{\mathrm{c}}$ & $3.84^{\mathrm{t}}$ \\
\hline \multicolumn{11}{|l|}{ Plantation } \\
\hline Natural Forest & $5.07^{\mathrm{c}}$ & $4.94^{\mathrm{a}}$ & $0.26^{\mathrm{a}}$ & $19.0^{\mathrm{a}}$ & $4.97^{\mathrm{a}}$ & $5.09^{\mathrm{c}}$ & $4.93^{\mathrm{a}}$ & $0.23^{\mathrm{a}}$ & $21.4^{\mathrm{a}}$ & $4.86^{\mathrm{a}}$ \\
\hline & \multicolumn{10}{|c|}{15 to $30 \mathrm{~cm}$ depth } \\
\hline Grass Land & $5.83^{\mathrm{a}}$ & $1.29^{\mathrm{b}}$ & $0.09^{\mathrm{b}}$ & $14.37^{\mathrm{b}}$ & $1.96^{\mathrm{d}}$ & $5.80^{\mathrm{a}}$ & $1.31^{\mathrm{b}}$ & $0.11^{\mathrm{b}}$ & $11.91^{\mathrm{b}}$ & $1.88^{\circ}$ \\
\hline $\begin{array}{l}\text { Cultivated } \\
\text { Land }\end{array}$ & $5.64^{\mathrm{b}}$ & $0.61^{\mathrm{c}}$ & $0.06^{\mathrm{c}}$ & $10.17^{\mathrm{d}}$ & $2.77^{\mathrm{b}}$ & $5.55^{\mathrm{b}}$ & $0.64^{\mathrm{d}}$ & $0.07^{\mathrm{c}}$ & $9.14^{\mathrm{d}}$ & $2.86^{\mathrm{b}}$ \\
\hline Eucalyptus & $5.28^{\mathrm{d}}$ & $1.10^{\mathrm{b}}$ & $0.08^{\mathrm{b}}$ & $13.24^{\mathrm{c}}$ & $2.19^{\mathrm{c}}$ & $5.29^{\mathrm{c}}$ & $1.07^{\mathrm{c}}$ & $0.10^{\mathrm{b}}$ & $10.70^{\mathrm{c}}$ & $2.25^{\circ}$ \\
\hline \multicolumn{11}{|l|}{ Plantation } \\
\hline Natural Forest & $5.40^{\mathrm{c}}$ & $3.03^{\mathrm{a}}$ & $0.18^{\mathrm{a}}$ & $16.86^{\mathrm{a}}$ & $3.70^{\mathrm{a}}$ & $5.36^{\mathrm{c}}$ & $2.93^{\mathrm{a}}$ & $0.17^{\mathrm{a}}$ & $17.23^{\mathrm{a}}$ & $3.49^{\circ}$ \\
\hline
\end{tabular}

${ }^{*}$ Means within a column followed by the same letter are not significantly different at $p \leq 0.05$;

$\mathrm{OC}=$ Organic carbon; $\mathrm{TN}=$ Total nitrogen; $\mathrm{C} / \mathrm{N}=$ carbon to nitrogen ration; $\mathrm{AP}=$ Available $\mathrm{P}$.

\section{Conclusions and Recommendations}

From the study, it was possible to conclude that soil physico-chemical properties significantly vary among land use systems. It was apparent that shift in land use systems from natural forest to other land use systems had detrimental effect on soil physical and chemical properties. Due to population pressure, large tracts of forest lands in Ethiopia had been converted to cultivated and grazing lands and some are put under artificial plantations dominated by eucalyptus species. Therefore, the remnant forests mainly found around church compounds could be used as benchmarks to evaluate our land resources. It is recommended that different integrated land management should be practiced to different land use systems to overcome land degradation and achieve sustainable agricultural production in cultivated lands of the study area. Moreover, attention should be given to aforestation schemes to combat land degradation and contribute towards mitigating climate change.

\section{Acknowledgement}

This paper is partially based on work conducted within the framework of the Swiss National Centre of Competence in Research (NCCR) North-South: Research Partnerships for Mitigating Syndromes of Global Change.

\section{References}

ADF (African Development Fund). (2001). Koga irrigation and watershed Management Project (Eth/Paai/2001/01) appraisal report, $\quad$ February $2001 . \quad$ Retrieved from http://www.afdb.org/fileadmin/uploads/afdb/Documents/Project-and-Operations/ET-2001-025-EN-ADF-B D-WP-COMPLET-KOGA-IRRIGATION-AND-WATERSHED-PROJECT.PDF 
Agbede, T. M. (2010). Tillage and fertilizer effects on some soil properties, leaf nutrient concentrations, growth and sweet potato yield on an Alfisol in southwestern Nigeria. Soil \& Tillage Research, 110(1), 25-32. http://dx.doi.org/10.1016/j.still.2010.06.003

Ahn, P. M. (1993). Tropical soils and Fertilizer use. Intermediate tropical agriculture serious. Malaysia: Long man Group UK Limited.

Ayoubi, S., Khormali, F., Sahrawat, K. L., \& Rodrigues de Lima, A. C. (2011). Assessing Impacts of Land Use Change on Soil Quality Indicators in a Loessial Soil in Golestan Province, Iran. Journal of Agricultural Science and Technology, 13, 727-742.

Barauah, T. C., \& Barthakulh, H. P. (1997). A textbook of soil analysis. Vikas Publishing House, New Delhi, India.

Berhane, F., \& Sahlemedhin, S. (2003). Assessment of the different phosphorus forms in some agricultural soils of Ethiopia. Ethiopian Journal of Natural Resources, 5(2), 193-213.

Blake, G. R., \& Hartge, K. H. (1986). Bulk density. In methods of soil analysis part physical and mineralogical properties (2nd ed.) (pp. 363-376). American society of agronomy, agronomy monograph no. 9. Madison, WI 53711, USA.

Brady, N. C., \& Weil, R. R. (2002). The nature and properties of soils (13th ed.). The Iowa State, India: PVT. Ltd.

Çelik, I. (2005). Land use effects on organic matter and physical properties of soil in a southern Mediterranean highland of Turkey. Soil and Tillage Res., 83, 270-277. http://dx.doi.org/10.1016/j.still.2004.08.001

Davidson, E. A., \& Ackerman, I. L. (1993). Changes in soil carbon inventories following cultivation of previously untilled soils. Biogeochemistry, 20, 161-193. http://dx.doi.org/10.1007/BF00000786

EFAP. (1994). Ethiopian Forestry Action Plan Volume 1: Executive summary. Ministry of Natural Resources Development and Environmental Protection, Addis Ababa, Ethiopia.

Evrendilek, F., Celik, I., \& Kilic, C. (2004). Changes in soil organic carbon and other physical soil properties along adjacent Mediterranean forest, grassland, and cropland ecosystems in Turkey. Journal of Arid Environonment, 59, 743-752. http://dx.doi.org/10.1016/j.jaridenv.2004.03.002

Fisseha, I. (2002). Micro- and macronutrient distributions in Ethiopian Vertisol landscapes. PhD dissertation,

Universitat Hohenheim, Germany.

Geissen, V., Guzman, G. M. (2006). Fertility of tropical soils under different land use systems-a case study of soils in Tabasco, Mexico. Applied Soil Ecology, 31, 169-178.

Gete, Z. (2002). Resource use and poverty in the Ethiopian high lands. In T. Amede (Ed.), Proceedings of the conference on: Natural resource degradation and environmental concerns in the Amhara: Regional State, Ethiopia: Impact On Food Security, March 2003. Bahir Dar, Ethiopia (pp. 51-61).

Gong, J. L., Chen, N. F., Huang, Y, Huang, Z., \& Peng, H. (2005). Effect of land use on soil nutrients in the Loess Hilly Area of the Loess Plateau, China. Land degradation and Development, 17(5), 453-465.

Havlin, J. L., Beaton, J. D., Tisdale, S. L., Nilson, W. L. (1999). Soil fertility and fertilizers: an introduction to nutrient management (6th ed.). Prentice Hall. Upper Saddle River, New Jersey.

Islam, K. R., \& Weil, R. R. (2000). Land use effects on soil quality in a tropical forest ecosystem of Bangladesh. Agricultural Ecosystems and Environment, 79, 9-16. http://dx.doi.org/10.1016/S0167-8809(99)00145-0

Heluf Gebrekidan and Wakene Negassa. (2006). Impact of land use and management practices on chemical properties of some soils of Bako area, western Ethiopia. Ethiopian Journal of Natural Resources, 8(2), 177-197.

Houghton, R. A. (1999). The annual net flux of carbon to the atmosphere from changes in land use 1850-1990. Tellus, 51B, 298-313.

Iwara, A. I., Ewa, E. E., Ogundele, F. O., Adeyemi, J. A., \& Otu, C. A. (2011). Ameliorating Effects of Palm Oil Mill Effluent on the Physical and Chemical Properties of Soil in Ugep, Cross River State, South-Southern Nigeria. International Journal of Applied Science and Technology, 1(5), 106-112.

Jackson, M. L. (1958). Soil chemical analysis (pp. 183-204). New Jersey: Prentice Hall, Inc.

Klute, A. (1965). Water holding capacity. In C. A. Black (Ed.), Methods of soil analysis. No. 9. part I, American society of agronomy (pp. 273-278). USA: Madison, Wisconsin. 
Khormali, F., Ajami, M., \& Ayoubi, S. (2006). Genesis and Micromorphology of Soils with Loess Parent Material as Affected by Deforestation in a Hillslope of Golestan Province, Iran (PP. 149-151). International Soil Meeting on Soils Sustaining Life on Earth, May 22-26, Sanliurfa-Turkey.

Lal, R. (2000). Soil management in the developing countries. Soil Science, 165(1), 57-72. http://dx.doi.org/10.1097/00010694-200001000-00008

Landon, J. R. (1991). Booker tropical soil manual: A hand book for soil survey and agricultural land evaluation with tropics and subtropics. Essex, New York: Longman scientific and technical.

Malo, D. D., Schumacher, T. E., \& Doolittle, J. J. (2005). Long-term cultivation impacts on selected soil properties in the Northern Great Plains. Soil Tillage Research, 81, 277-291. http://dx.doi.org/10.1016/j.still.2004.09.015

Materechera, S. A., Mkhabela, T. S. (2001). Influence of land-use on properties of a ferralitic soil under low external input farming in southern Swaziland. Soil and Tillage Res., 62, 15-25. http://dx.doi.org/10.1016/S0167-1987(01)00202-1

Mesfin, A. (1998). Nature and Management of Ethiopian Soils. Haramaya University, Alemaya, Ethiopia.

Mohammed, A. P., le Roux, A. L., Barker, C. H., \& Heluf, G. (2005). Soils of Jelo Micro-Catchment in the Chercher highlands of eastern Ethiopia: I. Morphological and physiochemical properties. Ethiop Journal of Natural Resources, 7(1), 55-81.

Offiong, R. A., Atu, J. E., Njar, G. N., \& Iwara, A. I. (2009). Effects of Land Use Change on Soil Physico-Chemical Properties in a South-Southern Nigeria. African Journal of environment, Pollution and Health, 7(2), 47-51.

Potter, C. S., Matson, P. A.,Vitousek, P. M., \& Davidson, E. A. (1996). Process modeling of controls on nitrogen trace gas emissions from soils worldwide. Journal of Geophysical Research, 101, 1361-1377. http://dx.doi.org/10.1029/95JD02028

Ronggui, W. (2001). Effect of land use on soil fertility and phosphorus dynamics in sub-alpine grassland soil of Gansu, China. Ph. D. Dissertation, University of Saskatchewan, Canada.

Sahlemedhin, S., \& Taye, B. (2000). Procedures for soil and plant analysis. National Soil Research Center, EARO, technical paper No.74, Addis Ababa, Ethiopia.

SAS. (1997). Statistical Analysis System. SAS Institute Inc., Cary. NC. USA.

Schlesinger, W. H. (1984). The world carbon pool in soil organic matter: A source of atmospheric CO2. In J. R. Trabalka, \& D. E. Reichle (Eds.), The Changing Carbon Cycle: A Global Analysis (pp. 111-124). New York: Springer-Verlage.

Shukla, M. K., Lal, R., \& Ebinger, M. (2006). Determining Soil Quality Indicators by FactorAnalysis. Soil Tillage Research, 87, 194-204. http://dx.doi.org/10.1016/j.still.2005.03.011

Solomon, D., Fritsch, F., Tekalign, M., Lehman, J., \& Zech, W. (2002). Soil Organic Matter Composition in the Subhumid Ethiopian Highlands as Influenced by Deforestation and Agricultural Management. Soil Science Society of America Journal, 66, 68-82. http://dx.doi.org/10.2136/sssaj2002.0068

Thomas, G. W. (1996). Soil pH and soil acidity. In D. L. Sparks (Ed.), Methods of soil analysis: part 3 chemical methods. Madison, WI: SSSA inc., ASA inc.

Thomas, S. J. (2000). Soil fertility evaluation. Sumner Handbook of soil science (pp. 159-164), United States of America: CRC presses, LLC.

Thompson, L. M., \& Troeh, F. R. (1993). Soils and Soil Fertility (5th ed.). Oxford University press.

Tuma, A. (2007). Effects of fruit based land use systems on soil physicochemical properties: The case of smallholders farming systems in Gamo Gofa, Southern Ethiopia. M. Sc. Thesis, Hawassa University, Awassa, Ethiopia.

United States Agency for International Development (USAID). (2004). Ethiopia land policy and administration assessment, Final Report with Appendices (p. 110), USAID Contract No. LAG-00-98-00031-00, Task Order No. 4, 2004. 
Vagen, T. G., Andrianorofanomezana, M. A., \& Andrianorofanomezana, S. (2006). Deforestation and Cultivation Effects on Characteristics of Oxisols in the Highlands of Madagascar. Geoderma, 131, $190-200$. http://dx.doi.org/10.1016/j.geoderma.2005.03.026

Wakene, N. (2001). Assessment of important physicochemical properties of Nitosols under different management systems in Bako Area, Western Ethiopia. M. Sc. Thesis, Alemaya University, Alemaya, Ethiopia.

Walkley, A., \& Black, C. A. (1934). An examination of Digestion method for determining soil organic matter and proposed modification of the proposed modification of the chromic acid titration method. Soil Sci, 37, 29-38. http://dx.doi.org/10.1097/00010694-193401000-00003

Wang, L., Tang, L. L., \& Wang, X. (2010). Effects of alley crop planting on soil and nutrient losses in the citrus orchards of the Three Gorges Region. Soil \& Tillage Research, 110(2), 243-250. http://dx.doi.org/10.1016/j.still.2010.08.012

Yihenew, G. S. (2002). Selected chemical and physical characteristics of soils of Adet Research Center and its testing sites in north-western Ethiopia. Ethiopian Journal of Natural Resources, 4(2), 199-215.

Zewdu, E., Giesler, R., \& Högberg, P. (2004). Historical land use pattern affects the chemistry of forest soils in the Ethiopian highlands. Geoderma, 118, 149-165. http://dx.doi.org/10.1016/S0016-7061(03)00190-3 